\title{
ArcheoSciences
}

Revue d'archéométrie

\section{Technological and material features of the gold work of Mesoamerica}

Caractéristiques technologiques et matérielles du travail de l'or en Mésoamérique

José Luis Ruvalcaba Sil, Gabriela Peñuelas Guerrero, Jannen Contreras Vargas, Edith Ortiz Díaz and Eumelia Hernández Vázquez

\section{CpenEdition}

Electronic version

URL: https://journals.openedition.org/archeosciences/2345

DOI: 10.4000/archeosciences. 2345

ISBN: 978-2-7535-1598-7

ISSN: $2104-3728$

Publisher

Presses universitaires de Rennes

Printed version

Date of publication: 31 December 2009

ISBN: 978-2-7535-1181-1

ISSN: $1960-1360$

\section{Electronic reference}

José Luis Ruvalcaba Sil, Gabriela Peñuelas Guerrero, Jannen Contreras Vargas, Edith Ortiz Díaz and Eumelia Hernández Vázquez, "Technological and material features of the gold work of Mesoamerica", ArcheoSciences [Online], 33 | 2009, Online since 10 December 2012, connection on 28 January 2022. URL: http://journals.openedition.org/archeosciences/2345 ; DOl: https://doi.org/10.4000/ archeosciences. 2345 


\title{
Technological and material features of the gold work of Mesoamerica
}

\section{Caractéristiques technologiques et matérielles du travail de l'or en Mésoamérique}

\author{
José Luis Ruvalcaba Sil*, Gabriela Peñuelas Guerrero**, \\ Jannen Contreras Vargas**, Edith Ortíz Díaz ${ }^{* * *}$ \\ and Eumelia Hernández VÁZquez ${ }^{* * * *}$
}

\begin{abstract}
The metallurgical work in Pre-Columbian America achieved a high degree of development. In the Mesoamerican area, the development of metallurgy started very late, during the post-Classic period (800 AD). Nevertheless, various techniques, such as lost wax casting and false filigree, were rapidly developed and improved. Most of the gold metallurgy was developed in the Oaxaca region, in the South of Mexico, by the Mixtec people.

A limited number of gold alloy based artefacts survived after the conquest of Mexico. Few collections are related to archaeological contexts and may be used to obtain reliable information about the technical features and materials used in the Mesoamerican gold metallurgy. For this reason, non-destructive analyses have been performed on some artefacts of the most important collections of the Mexican museums using portable XRF and PIXE in the laboratory.

In this work, a full review of the main technical features and alloys of the analyzed gold artefacts from the Mesoamerican area collections are presented. This database may be used to study collections of gold artefacts from the Mesoamerican areas.
\end{abstract}

Résumé : Le travail du métal a atteint un niveau élevé en Amérique précolombienne. Dans l'aire Mésoaméricaine, ce développement débute très tard, pendant la période postclassique (800 AD). Néanmoins, différentes techniques, notamment la fonte à la cire perdue et le faux filigrané, rapidement se développent et se perfectionnent. La majeure partie de la métallurgie de l'or a été développée par le peuple Mixtèque dans la région d'Oaxaca, au sud du Mexique.

Seul un nombre limité d'objets fabriqués avec des alliages d'or ont survécu à la conquête du Mexique. Quelques rares collections possèdent des objets dont les contextes archéologiques sont connus et peuvent ainsi être utilisées pour obtenir des informations fiables sur les procédés techniques et les matériaux utilisés en Mésoamérique dans le cas de la métallurgie de l'or. Pour cette raison, une sélection d'objets appartenant aux plus importantes collections des musées mexicains a été analysée d'une façon non-destructive au moyen d'une FX portable et par PIXE au laboratoire.

Ce travail présente un bilan complet des procédés technologiques et des alliages des objets mésoaméricains en or étudiés. La base de données obtenue peut être appliquée à l'étude de collections d'objets en or fabriqués dans l'aire mésoaméricaine.

Keywords: Mesoamerica, gold, depletion gilding, PIXE, XRF.

Mots-clés : Mésoamérique, or, mise en couleur, PIXE, XRF.

* Instituto de Fisica, Universidad Nacional Autónoma de México - Apdo. Postal 20-364 Mexico DF 01000, Mexico. (sil@fisica.unam.mx)

** Escuela Nacional de Conservación, Restauración y Museografia-INAH - General Anaya 187 Col. San Diego Churubusco, Coyoacán, cp, 04120. México D.F. (gabrielapenuelas@gmail.com), (jannencontreras@gmail.com)

*** Instituto de Investigaciones Antropológicas, Universidad Nacional Autónoma de México - Circuito Exterior s/n, Ciudad Universitaria, Mexico DF 04510, Mexico. (edithd@servidor.unam.mx)

**** Instituto de Investigaciones Estéticas, Universidad Nacional Autónoma de México - Circuito Mario de la Cueva s/n, Ciudad Universitaria, Mexico DF 04510, Mexico. (euihernandez@gmail.com) 


\section{INTRODUCTION}

The main cultural area extending approximately from contemporary central Mexico to Honduras and Nicaragua is called Mesoamerica (Fig. 1). In this area, several civilizations and cultures developed from $1500 \mathrm{BC}$ until the Spanish conquest in the $16^{\text {th }}$ century AD. Despite the fact that Mesoamerican cultures achieved a significant degree of development in agriculture, mathematics, astronomy, calendaric and technological knowledge, metallurgy appeared in specific areas quite late, around $800 \mathrm{AD}$. It is generally accepted that the first metallic artefacts and metalwork knowledge arrived to Western and Southern Mexico and the Yucatan peninsula from Central America, Colombia and Peru by several paths (Fig. 1). First, the artefacts arrived as a result of exchange. Some of the basic forms were copied and afterwards modified following local and cultural influ- ences (Hosler, 1995). Later, the metalwork focus in Western Mexico and in Oaxaca - South of Mexico - developed rapidly, with local and original contributions that gave rise to a high level of technical manufacturing of artefacts.

Copper metallurgy was developed especially in Western and Central Mexico, while gold and silver were mainly worked in the Oaxaca area, in the South of Mexico. Apparently, the mineral and metal sources available in these regions determined these specific developments. Gold was obtained mainly from rivers, as powder and nuggets. Mining and gold extraction were not developed until the conquest and Spanish colonization.

By the end of the Mesoamerican Age, copper and gold metallurgy became widespread in Western and Central Mexico, and the metallic artefacts were traded and used by the elites of the Mesoamerican peoples both as symbols of power and for ritual purposes in offerings and burials. Only

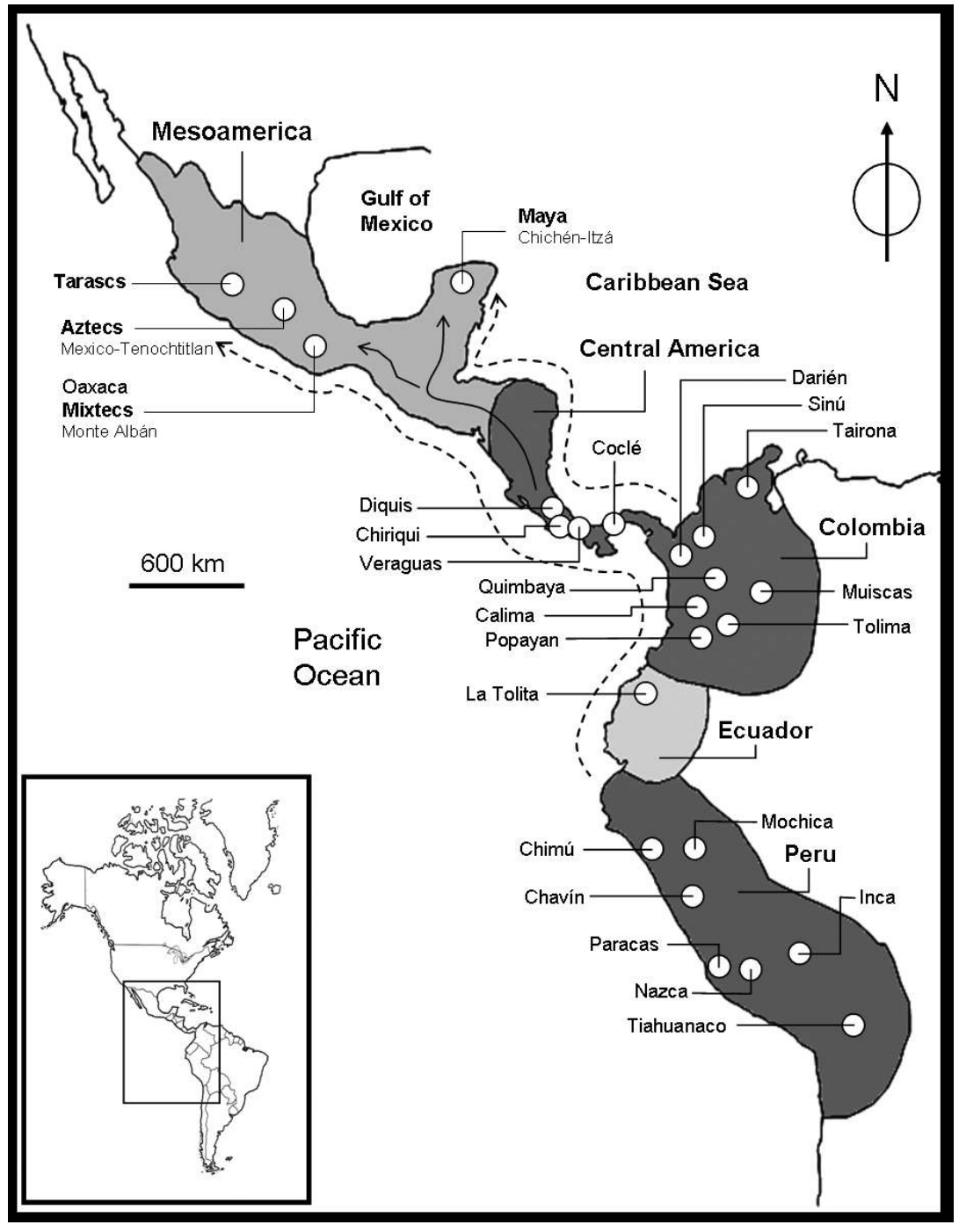

Figure 1: Map of the areas of Mesoamerican and South American gold work traditions. The possible routes of contact are shown.

Figure 1: Carte des aires de tradition orfevre mésoaméricaine et sud-américaine. Les routes probables de contact sont visibles. 
high level rulers and warriors were allowed to wear metallic artefacts. Gold and silver were considered symbols of the sun and moon. Nevertheless, precious metals did not have monetary value. In fact, other materials such as green stone objects or fully coloured feathers had a high value and were much appreciated by the Mesoamerican cultures. Most of the usual artefacts were ornaments: chin ornaments, ear ornaments, rings, pendants, necklaces and foils.

\section{GOLD COLLECTIONS FROM MESOAMERICAN AREAS}

Few gold based artefacts from Mesoamerica survived the European destruction and the ambition for gold and silver. In Europe and North America, there are few items that are representative of the goldsmiths' technological skills and developments (Matos Moctezuma and Solis, 2003). The Mexican collections are composed of items recovered mainly from archaeological excavations of burials and offerings. They may be used to infer reliable information about the technical features and materials used in the Mesoamerican gold metallurgy. The Mesoamerican collections of Mexico correspond to the Maya area, West Mexico, Aztec gold artefacts, and the sets from the Oaxaca region (Solis, 2004).

\section{The Maya}

The gold artefacts discovered in the Maya area originate mainly from the Yucatan region. In fact, most of the artefacts were recovered from the Chichen Itza Cenote during the first decade of the $20^{\text {th }}$ century. These items were part of offerings and ritual ceremonies. Their chronology corresponds to the post-Classic period (800-900 AD), but, judging by the style, shape and size of the artefacts, it is clear that these zoomorphic pieces, bells and pendants were traded from the Central American peoples Diquis and Veraguas (Fernández and Segura, 2004). Only a few foils in the shape of serpents may have been manufactured in the Maya area. This represents the biggest collection of gold artefacts discovered in Mesoamerica, but we have to take into consideration the fact that it is not representative of the local metal work technology. Most of the artefacts are currently on display in the Peabody Museum. Part of the collection was given back to Mexico, and they are exhibited in the Maya room of the National Museum of Anthropology and History of Mexico (MNAH), and in the Yucatan Museum of Palacio Canton.

\section{Artefacts from West Mexico}

One of the major loci of metallurgy in Mesoamerica was the Western region, ruled by the Tarascan, rivals of the Aztecs. They used extensively copper based artefacts for ornaments and weapons. Nevertheless, a limited number of gold artefacts have also been discovered in this region. Most the artefacts are bells, plates, zoomorphic items and ear ornaments with clear stylistic influences from South America.

\section{Aztec gold artefacts}

The artefacts belonging to the Aztec culture were discovered during excavations in Mexico City and among the offerings found in the remains of the archaeological site of the main temple of Tenochtitlan, the capital city of the Aztecs, in the historic centre of Mexico City (Matos Moctezuma and Solís, 2003). The sets of artefacts are part of the collections of MNAH and the Museum of the Great Temple of Tenochtitlan (MTM). They are small plates, pendants and bells decorated with false filigree, and correspond to the period of 1325-1521, the dates of the foundation and conquest of Tenochtitlan, respectively.

The gold raw materials, such as powder and ingots, or even foils, were brought from the Oaxaca and Guerrero regions, as tributes from the peoples under Aztec rule. The historical registers indicate the amounts of gold provided by the different regions of the Aztec Empire. Manufactured pieces may also be originating from tributes, but pendants and other items were especially offered as presents for rulers, priests or elite warriors. The historical sources indicate that goldsmiths from the Oaxaca area worked in the Aztec workshops to produce artefacts for the Aztec rulers and ceremonies. The Florentine Codex, written under the supervision of the Franciscan priest Sahagun in the second part of the $16^{\text {th }}$ century, describes in the ninth book the manufacturing process and technology employed by the goldsmiths to produce the gold artefacts by lost wax casting and depletion gilding (Sahagun, 2000).

The most outstanding artefacts were discovered among the MTM offerings: a few pendants with spherical beads with a clay nucleus; however, most of the items are gathered in practically three offerings only (\#3, \#34 and \#126). Unfortunately, most of the smaller items were melted, since the items of the offering were often fired, and they appeared as small solid beads in the archaeological context. 


\section{Mixtec artefacts}

The Mixtecs were the most skilled goldsmiths of Mesoamerica. Their civilization developed in the Oaxaca regions during the post-Classic period (from $900 \mathrm{AD}$ until the conquest) and replaced the Zapotecs, the dominant culture during the Classic period in Oaxaca, in various sites of the Central Valleys.

About $80 \%$ of the existing Mesoamerican gold artefacts belong to the Mixtec tradition. The most important collections are in the Oaxaca Room of the MNAH, in the Museo de las Culturas de Oaxaca (MCO), and in the Fisherman's Treasure in the Baluarte de Santiago in Veracruz (BSV).

The collection of MNAH is composed of artefacts from various regions of the Oaxaca area: the Central Valleys and the Sierra. The collection includes pendants, chin ornaments (bezotes), zoomorphic pieces, necklaces, rings and ear ornaments, bells, foils, etc. Some of the artefacts were acquired at the beginning of the last century and they lack an archaeological context. Nevertheless, the main gold artefacts from the tombs of Zaachila and other artefacts discovered in archaeological contexts are also on display. Among the Zaachila pieces, a huge solar pendant made by the lost wax technique, fully decorated ring ornaments and chin ornaments, as well as ear pieces, are exhibited. The Papantla pendant, discovered in the Gulf of Mexico area but belonging to the Oaxaca tradition, is an exceptional piece, similar in terms of technological manufacturing to the finds of Tomb 7 of Monte Alban.

The most outstanding gold treasure of pre-Hispanic Mexico was discovered in 1934 at Monte Alban, in a tomb reused by the Mixtec people (Caso, 1969). In this multiple burial, artefacts made of green stones, turquoises, shells, bones, gold and silver were found. About 121 gold artefacts and 24 silver pieces were found. All types of artefacts were discovered, such as sets of remarkable pendants, fully decorated rings, bells, rich necklaces, strings of beads, ear pieces, chin ornaments, etc. The collection includes sets of almost identical pendants and finger ornaments, with practically the same decoration in gold and silver alloys (Fig. 2, a-c and Fig. 3).

The third collection is located in the port of Veracruz, on the Gulf coast of Mexico. It was recovered from the sea by a fisherman who sold part of the items to a jeweller. Fortunately, an important number of artefacts were not melted. The treasure is attributed to the shipwreck of the boat on which the entrusted Figueroa was returning to Spain after looting tombs in the Sierra of Oaxaca. The collection of 40 pieces includes beautiful pendants, seven bracelets, fully decorated beads, zoomorphic pieces, discs, as well as two ingots. According to their style and shape, the artefacts undoubtedly share features with the Oaxaca artefacts of the $\mathrm{MNAH}$, and with the MCO pieces.
Following the main discoveries described above, few gold artefacts have been found in the Oaxaca area in recent times. One such case is that of the San Francisco Caxonos site in the Sierra region, where a pendant was recovered (Fig. 2d). This artefact was fully studied using various non-destructive techniques, since it is remarkable in terms of the technology used for its gilding (Ortiz Diaz and Ruvalcaba, 2009).

\section{Main Metallurgical Techniques and Technological Features}

The amount of gold artefacts from Mesoamerica is limited in comparison with South American metallic objects. Nevertheless, it is possible to infer some patterns related to the materials used, as well as technological features.

First, all the types of gold artefacts from Mesoamerica were manufactured in combination with other precious materials, such as green stones, turquoise, obsidian, crystal rock and sea shells. In very few cases, two examples actually, symmetric bimetallic artefacts, with one half made from a silver-rich alloy and the second half made using a gold-rich alloy, were cast. The first example, a pendant from Teotitlan, Oaxaca, is currently on display in the Oaxaca room of the MNAH collection, and the second case is that of the set of two discs from Tomb 7 of the Monte Alban collection in the MCO.

The main difficulties in the study and characterization of the artefacts are, first of all, the limited number of items, and, second, the fact that, since they belong to museum collections, it is generally not possible to move them to the laboratory for technological analyses. Moreover, sampling is not allowed or is limited. Thus, the analytical approach that we have considered in our research is that of performing non-destructive analyses in situ by imaging techniques, in order to detect restorations and mounting materials, followed by microscopic studies with a 40-80X stereoscope, and finally by elemental analysis by XRF (Peńuelas Guerrero, 2008).

The main techniques used to fabricate the Mesoamerican artefacts are hammering for the foils and plates, and lost wax casting using a nucleus of a mixture of clay and carbon. This manufacturing technique allowed the optimization of the amount of gold alloy required for the casting. In fact, native gold was not as abundant in Mesoamerica as we may expect. Undoubtedly, the false filigree technique was developed and improved in comparison with the South American artefacts. All the finest details employed to simulate the threads were produced by lost wax casting. This technique was also used to produce granulations (false gra- 


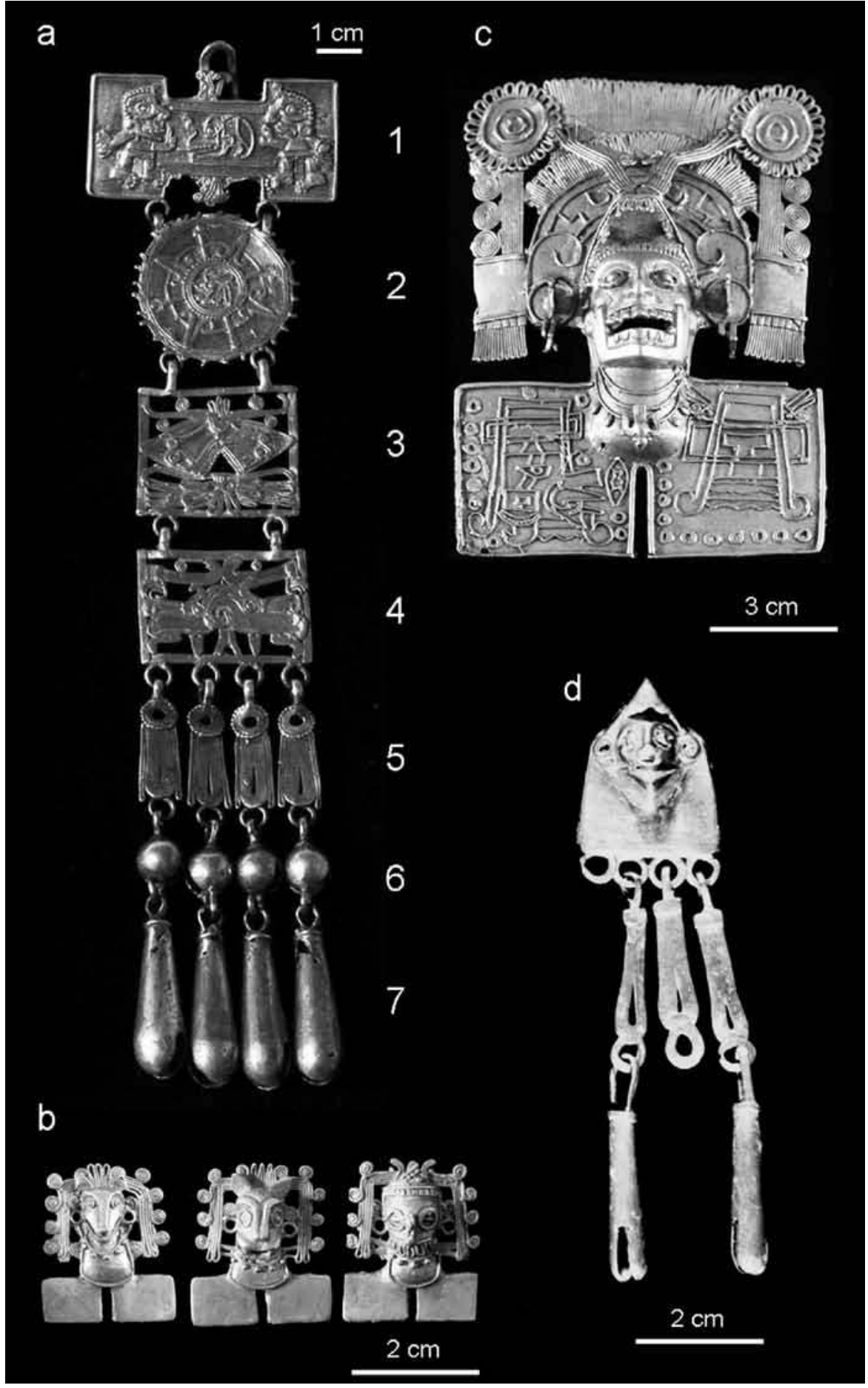

Figure 2: (See colour plate) Various artefacts from Tomb 7 of Monte Alban: a) Pendant with dates, b) zoomorphic pendants, c) Ball game pendant, and d) Warrior pendant from Caxonos, Sierra of Oaxaca.

Figure 2 : (Voir planche couleur) Différents objets de la Tombe 7 de Monte Alban: a) Pendentif avec dates, b) pendentifs zoomorphes, c) pendentif au jeu de bale et d) pendentif au guerrier de Caxonos, Sierra of Oaxaca. 


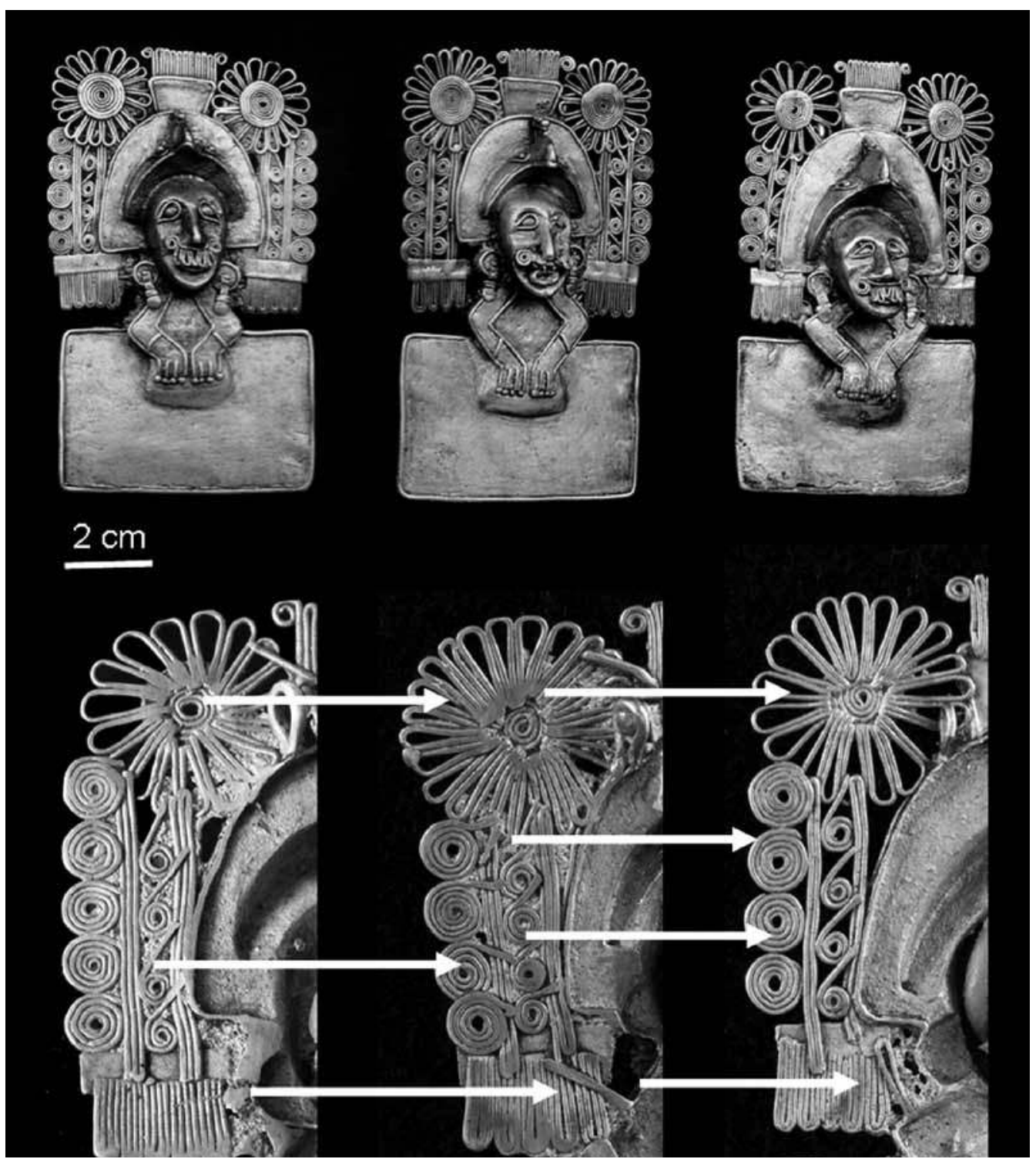

Figure 3: Three of five of the Xochipilli pendants set of Tomb 7 of Monte Alban. Details of false filigree modelling are shown. Figure 3 : Trois des cinq pendentifs Xochipilli de la Tombe 7 de Monte Alban. Détails du faux filigrane. nulation) and mesh decorations. After hundreds of analyses using XRF and PIXE (Cesareo et al., 1994; Ruvalcaba et al., 1995; Peńuelas Guerrero, 2008), as well as SEM-EDS measurements carried out on the artefacts (La Niece and Meeks, 2000), no indication of soldering has ever been observed in the Mesoamerican gold artefacts.

The collection of Tomb 7 of Monte Alban provides outstanding information about the modelling and lost wax casting of the metal work. Since this collection includes sets of almost identical pendants and finger ornaments, from a careful examination it is clear that they were produced in series in the same workshops, following the same iconography, size and decoration. However, the back parts show small differences in the wax modelling of the threads, and the unions of the various parts in the original model (Fig. 3). Thus, each object is in fact unique, despite their similarity. Also, the composition of the gold alloys used, determined by XRF, indicates that the same alloys were used to cast one set of pieces, like in the case of the small zoomorphic pendants (78\% Au, 13\% Ag, 9\% Cu) of Figure 2b. Nevertheless, the sets may have different compositions as well. For example, four of the five pendants of the Xochipilli goddess in Figure 3 have the same composition ( $47 \% \mathrm{Au}, 33 \% \mathrm{Ag}, 20 \% \mathrm{Cu}$ ), but for the fifth piece the elemental contents are different (54\% Au, 26\% Ag, 20\% Cu). The difference in the composition of these sets may suggest two different workshops.

The elemental analysis of the huge ball game pendant (Fig. 2a) indicates that three alloys were used to manufacture this 
artefact; the first four sections have a similar composition (59\% Au, 26\% Ag, 15\% Cu), while for the feathers section (5), the mean composition is completely different (50\% Au, $38 \% \mathrm{Ag}, 12 \% \mathrm{Cu}$ ), and it also changes slightly for the bits and bells sections 6 and $7(50 \% \mathrm{Au}, 36 \% \mathrm{Ag}, 15 \% \mathrm{Cu})$. This behaviour has also been observed for the eagle chin ornament from the Zaachila tombs and for the Caxonos pendant (Fig. $2 \mathrm{~d})$. From these results, we may infer that the casting of this kind of pieces was carried out by rows, sometimes using the same alloy, and in other cases different alloys, as a function of the amount of available materials. A comparison of the mean composition of the artefacts of Tomb 7 of Monte Alban and other collections indicates that the Mixtec goldsmiths were able to produce a significant number of alloys with similar composition, but also that they were using similar native gold sources to manufacture the artefacts.

On the other hand, in terms of finishing the items, the historical sources report the use of a depletion gilding technique (mise-en-couleur) by successive oxidation and cleaning of a gold-poor alloy. According to this technique, the amount of gold increases gradually at the surface due to the elimination of copper and the consequent nucleation of gold (Bray, 1993; Ruvalcaba et al., 2004); however, so far this was only identified in one piece from Mesoamerica. This is the case of the warrior pendant discovered at the San Francisco Caxonos site in Oaxaca (Fig. 2d). When this kind of depletion gilding is used, we may expect that the surface composition presents both lateral and depth heterogeneity because of the irregular loss of copper by pickling and the dynamics of gold nucleation during heating. X-ray based techniques, such as EDS, PIXE and XRF, provide the mean elemental composition, and only by changing the incident beam energy and performing the analysis on several regions of the surface it is possible to detect this heterogeneity and the use of a depletion gilding technique (Demortier and Ruvalcaba, 1998). For the Caxonos pendant, differential PIXE combined with RBS was applied to determine the gold enrichment depth profile, ranging from $50 \%$ gold content in the bulk up to practically $100 \%$ gold concentration at the upper surface, on the first $4 \mu \mathrm{m}$ depth. Copper concentration may reach more than $35 \%$ in the bulk (Demortier and Ruvalcaba, 2005; Ortiz Diaz and Ruvalcaba, 2009).

According to the data reported in analytical studies, it is possible to show in Figure 4 the composition of the gold alloys of the Mesoamerican items by regions (Franco Velazquez and Torres Montes, 1989; Cesareo et al., 1994; Ruvalcaba et al., 1995; Ortiz Diaz and Ruvalcaba, 2009; Peñuelas Guerrero, 2008). In this figure, the data for the Maya artefacts imported from Central American regions show high amounts of gold (higher than 90\%) and do not fit with the composition of other Mesoamerican regions. On the other hand, the data for the Aztec collection overlaps
Figure 4: Comparison of the elemental composition of gold artefacts from the main Mesoamerican areas.

Figure 4 : Comparaison de la composition élémentaire d'objets d'or des principales aires mésoaméricaines.

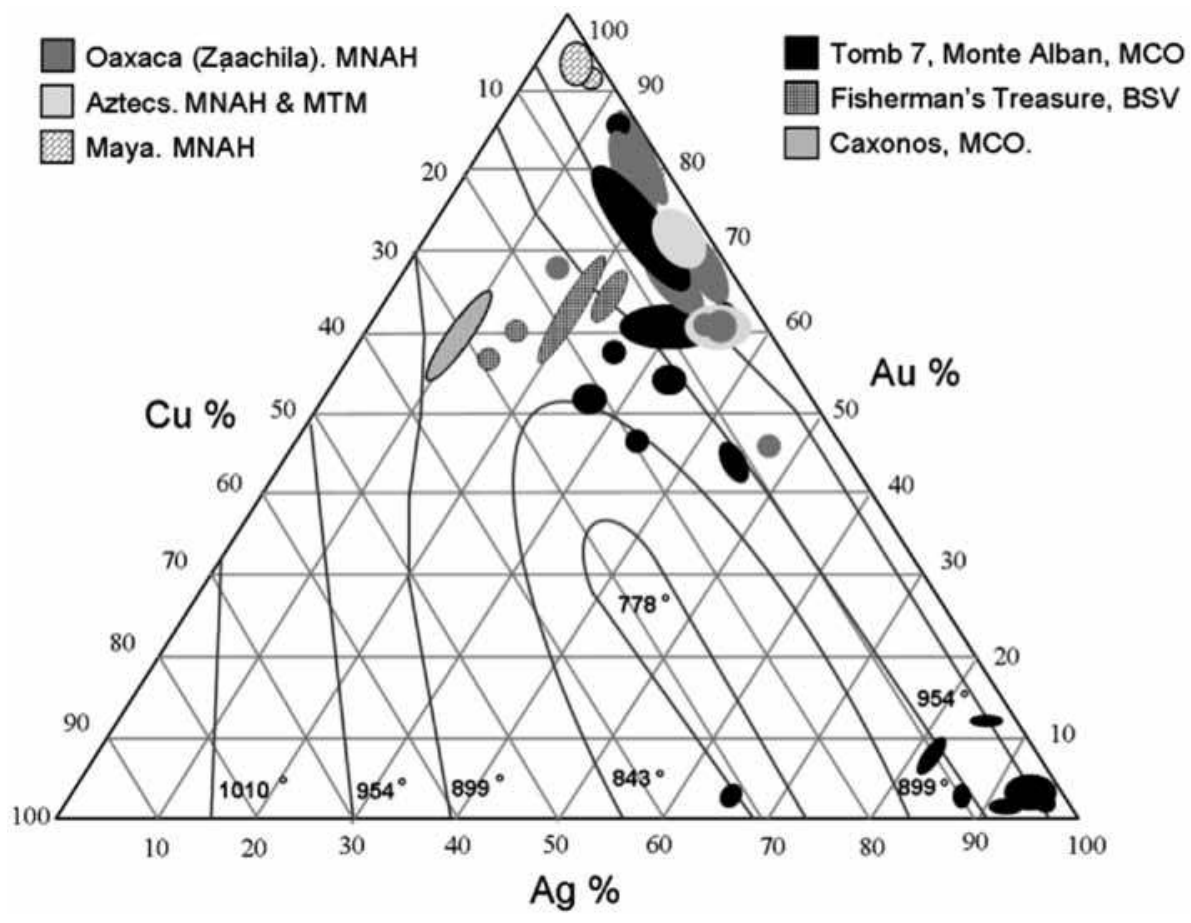

ArCheoSciences, revue d'archéométrie, 33, 2009, p. 289-287 
with that pertaining to the artefacts from the Central Valleys of Oaxaca, made by the Mixtec goldsmiths. The compositions of the gold alloys range from 60 up to $85 \%$ gold, and may reach about $20 \%$ copper; the silver contents rises from 10 to $40 \%$. Nevertheless, the artefacts from the Sierra of Oaxaca (Caxonos and Fisherman's Treasure) do not fit very well with the composition of the Central Valley and Aztec pieces. Their gold alloys are richer in copper (from 10 to $40 \%$ ) and silver amounts vary from 10 to $35 \%$. There is a difference of about $60^{\circ} \mathrm{C}$ in the melting temperatures of the alloys. Also, depletion gilding may have been used, since the amount of copper is significantly higher. For these reasons, the hypothesis of two loci of metal work, one including the Oaxaca area and the Central Valleys, and the other the Sierra, has been proposed.

These data may be used as a reference for Mesoamerican style artefacts without an archaeological context or reported provenance. For instance, the composition of the gold artefacts from the British Museum fits perfectly our reported data for the Central Valley artefacts.

Finally, a comparison of the reported data for Mesoamerican pieces with the gold alloys measurements carried out for the Panama traditions (Veraguas and Cocle) and some Colombian cultures (Calima, Tolima and Muisca) indicates an overlap between the Veraguas items and the Maya artefacts from the Cenote of Chichen Itza, as it may be expected, while the Colombian pieces show some similarity with the pieces from Oaxaca areas.

\section{Final Remarks}

Despite the fact that metallurgy developed quite late in Mesoamerica - after $800 \mathrm{AD}$ - a quick development and high technological level were achieved in the manufacturing of gold artefacts after this date.

A limited number of objects (less than 500 pieces) have been preserved. From the analyses of these items, we can infer reliable information about the work and skills of Mesoamerican goldsmiths; in particular, they were masters of the false filigree and false granulation techniques.

There are very few cases of artefacts finished by depletion gilding. This fact may be due to the low amount of copper in the gold alloys. Other gilding techniques, such as electrochemical replacement plating, have been observed in imported artefacts recovered in the Maya region of Yucatan (Contreras et al., 2007). So far, there is no technical evidence of soldering techniques.

Since the collections are unique, it is difficult to access the items. Thus, in situ analysis represents a convenient first step that might justify further analyses in the laboratory, and/ or establish a suitable strategy for sampling with minimal damage to the artefact.

\section{Acknowledgements}

This research is part of the MOVIL project Non destructive methodologies for the study of the Mexican cultural heritage, with the financial support of the CONACyT Mexico U49839-R.

\section{References}

BRAY, W., 1993. Techniques of gilding and surface enrichment in preHispanic American metallurgy, in S. La Niece, P. Craddock (eds.), Metal Plating and Patination: Cultural, Technical and Historical Developments. Oxford: Butterworth Heinemann, 182-192.

Caso, A., 1969. El Tesoro de Monte Albán. Memorias del Instituto Nacional de Antropologia e Historia III. México: Instituto Nacional de Antropologia e Historia.

Cesareo, R., Gigante, G.E., Iwanczyk, J.S., Rosales, M.A., Aliphat, M. and Ávila, P., 1994. Non-destructive analysis of pre-Hispanic gold objects using energy dispersive X-ray fluorescence. Revista Mexicana de Física 40(2): 301-308.

Contreras, J., Ruvalcaba Sil, J.L. and Arenas Alatorre, J., 2007. Non destructive study of gilded copper artifacts from the Chichen-Itza Cenote, in Proceedings of the XI International Conference on Particle Induced X-rays Emission and its Analytical Applications, Puebla, Mexico, May 25-29, 2007. México, Universidad Nacional Autonóma de México (CD-ROM).

Demortier, G. and Ruvalcaba Sil, J.L., 1998. Differential PIXE Analyses of Mesoamerican Jewelry Items. Nuclear Instruments and Methods in Physics Research B 118: 352-355.

Demortier, G. and Ruvalcaba Sil, J.L., 2005. Non-destructive ion beam techniques for the depth profiling of elements in Amerindian gold jewellery artefacts, in R. Van Grieken, K. Janssens (eds.), Cultural Heritage Conservation and Environmental Impact Assessment by Non-destructive Testing and Microanalysis. London, A.A. Balkema Publishers, 91-100.

Fernández, P. and Segura, J., 2004. Metalurgia del sureste de Costa Rica: Identificación de Producciones Locales basadas en evidencia Tecnológica y estilistica, in A. Perea, I. Montero, O. García-Vuelta (eds.), Primer Simposium Internacional sobre Tecnología del Oro Antiguo SITOA. Anejos de Archivo Español de Arqueología XXXII. Madrid, CSIC, 49-61.

Franco Velazquez, F. and Torres Montes, L., 1989. La orfebrería prehispánica en el Golfo de México y el Tesoro del Pescador, in C. Aguilar (ed.), Orfebrería prehispánica. México, Corporación Industrial San Luis, 217-271. 
Hosler, D., 1995. Sound, color and meaning in the metallurgy of ancient west Mexico. World Archaeology 27(1): 100-115.

La Niece, S. and Meeks, N., 2000. Diversity of Goldsmithing Traditions in the Americas and the Old World, in C. McEwan (ed.), Pre-Columbian Gold, Technology, Style and Iconography. London, Fitzroy Dearborn Publishers, 220-239.

Matos Moctezuma, E. and Solis, L.F., 2003. Aztecs. London, Royal Academy Books.

Ortiz-Diaz, E. and Ruvalcaba Sil, J.L., 2009. An historical approach to a gold pendant: The study of different metallurgic techniques in ancient Oaxaca, Mexico, during the late postclassic period, in Archaeometallurgy in Europe: 2nd International Conference, Aquileia, Italy, 17-21 June 2007: selected papers. Milano, Associazione Italiana di Metallurgia, 511-518.

Peñuelas Guerrero, G., 2008. Caracterización por Medio de Análisis Instrumentales de los Materiales Constitutivos de la Orfebreria de la Tumba 7 de Monte Albán, Oaxaca. México,
Esc. Nal. de Restauración. Conservación. y Museografía, Instituto Nacional de Antropologia e Historia.

Ruvalcaba Sil, J.L., Demortier, G. and Oliver, A., 1995. External beam PIXE analysis of gold pre-Hispanic Mexican jewelry. International Journal of PIXE 5: 273-288.

Ruvalcaba Sil, J.L., Torres, L., Franco, F. and Ortiz Díaz, E., 2004. Artifacts rich surfaces: Depletion gilding or natural surface corrosion? Study of corrosion and oxidation of gold alloys, in A. Perea, I. Montero, O. García-Vuelta (eds.), Primer Simposium Internacional sobre Tecnología del Oro Antiguo SITOA. Anejos de Archivo Español de Arqueología XXXII. Madrid, CSIC, 41-47.

Sahagun, B., 2000. Historia General de las Cosas de la Nueva España. México, Conaculta, Colección Cien de Mexico.

Solís, L.F. and Carmona, M., 2004. Oro Precolombino de Mexico Colecciones Mixteca y Azteca. IXE -Landucci-Mogilner eds. Hong Kong. 
